\title{
Leadership Styles and Organizational Learning An Empirical Study on Saudi Banks in Al-Taif Governorate Kingdom of Saudi Arabia
}

\author{
Wageeh A. Nafei \\ MenoufiaUniversity \\ Shebin El-Kom, Menoufia \\ Arab Republic of Egypt \\ Tel: + 11-20-100-192097Ｅ-mail: dr.wageeh@yahoo.com \\ Nile M. Khanfar (Corresponding author) \\ Nova Southeastern University \\ 11501 N. Military Trail \\ Palm Beach Gardens, Florida 33410 USA \\ Tel:+1-561-805-2242Ｅ-mail: khanfar@nova.edu \\ Belal A. Kaifi \\ Trident University International \\ 5757 Plaza Drive, Suite 100 \\ Cypress, California 90630 USA \\ Tel: +1-925-526-5277Ｅ-mail: bkaifi@tuiu.edu
}

Received: July 22, $2011 \quad$ Accepted: October 9, $2011 \quad$ Published: February 15, 2011

doi:10.5430/jms.v3n1p2

URL: http://dx.doi.org/10.5430/jms.v3n1p2

\begin{abstract}
This paper investigates how two important research streams, namely Leadership Styles (LS) and Organizational Learning (OL), might be related. In other words, LS and OL represent two rich lines of research: one is about how people lead and the other is about how people learn. Specifically, this contribution addresses two issues (1) the evaluative attitudes of the employees towards LS and OL and (2) the relationship between LS and OL.

This study was conducted at Saudi banks in Al-Taif Governorate, Kingdom of Saudi Arabia. This research is practical, according to its purpose, and descriptive according to its data collection method. Three groups of employees at Saudi banks were reviewed. Of the 335 questionnaires that were distributed, 285 usable questionnaires were returned, a response rate of $85 \%$. The finding reveals that there are differences among the three groups of employees regarding their evaluative attitudes towards LS and OL. Also, this study reveals that the aspects of LS have a significantly direct effect on OL.

Accordingly, the study provides a set of recommendations that included the need for Transactional Leadership Styles (TALS) in general, and Transformational Leadership Style (TFLS) in particular, in order to achieve the best response to the needs and wishes of the workers at Saudi banks to increase their contribution to the achievement of OL on the one hand, and raise the level of their performance and enhance competitive advantage of these organizations on the other hand.
\end{abstract}

Keywords: Leadership styles, Transactional and transformational leadership styles, Organizational learning

\section{Introduction}

As organizations continuously improve and evolve, the role of a leader becomes more demanding and important. Leaders are known to be visionary, influential, charismatic, and even altruistic. As a result, leaders play a significant role in building high-performing teams who have high levels of job satisfaction and organizational commitment. Many 
leaders are facing greater challenges than ever before due to increased environmental complexity and the changing nature of organizations (Riaz\&Haider, 2010).

In short, effective leadership is the main cause of competitive advantage for any kind of organization (Lado et al., 1992; Avolio, 1999; Rowe, 2001; Zhu et al., 2005). Leaders are conferred the opportunity to lead, not because they are appointed by senior managers; they lead because they are perceived and accepted by followers as leaders (Boseman, 2008).

In fact, a leader is responsible for not only leading but also providing followers with the tools that are needed to accomplish organizational goals. In the event that a leader is unable to provide the adequate information or resources that are needed, a conflict may arise rooted in distrust and de-motivation. Thus, a leader's role is very delicate and every action or decision must be very strategic. Leaders can anticipate future likelihoods and plan alternative strategies to meet uncertainties. Such traits are common in historical leaders. This sense of anticipation is believed to be innate and cannot be learned (Riaz\&Haider, 2010).

The interest in the recent issue of Leadership Style (LS) and Organizational Learning (OL) has increased. There is near consensus among researchers in the field of organizational research on the importance of these basic concepts to understand and interpret the performance of organizations on the one hand, and the behavior of individual employees, on the other hand (Edmondson, 1999; Coad \& Berry, 1998; Popper \& Lipchitz, 2000; Lipshitz, et al., 2002).

Since organizations face a lot of environmental pressures, there is an urgent need to change, so change is possible and must be done through the process of $\mathrm{OL}$, and the beginning of the movement of change is through leadership by transforming the culture of the old work to a new culture (Lakomski, 2001). This is in addition to the fact that the leadership is responsible for the education and rehabilitation of individuals in the organization (Agshae\& Bratton, 2001).

It must be noted that there is a need to conduct more research in order to test the relationship between LS and OL, because the methods of leadership that can lead to OL need further analysis and verification to be applied (Amitay, et al., 2005).

In light of the above, this research seeks, through investigation and analysis, to identify the Transactional Leadership Style (TALS: contingent rewards and management by exception), and Transformational Leadership Style (TFLS: individual considerations, charismatic-inspiration, and intellectual simulation). Evaluation of its impact on OL, in terms of Adaptive Organizational Learning (AOL) and Generative Organizational Learning (GOL), among workers at Saudi banks in Al- Taif Governorate, Kingdom of Saudi Arabia, was also conducted.

This study aims at identifying the extent of similarities or differences among the various categories of employees at Saudi banks in Al-Taif Governorate, KSA in regard to LS and OL. The type and degree of the relationship between LS and OL were also addressed.

This article consists of five sections. The first section provides a theoretical construct of LS and OL. This includes the theoretical background of TALS and TFLS. In addition, this section deals with the theoretical background of OL. The second section presents the research design. The third section deals with the study methodology. This includes the population and sample of research, the procedure of data collection, the research variables and method of measuring, and an overview of the statistical tests used in the study. The fourth section presents the empirical results and discussion. The last section embraces the main conclusions of the study and some recommendations for LS and OL at Saudi banks in Al-Taif Governorate, Kingdom of Saudi Arabia.

\section{Theoretical Background}

This section gives the reader an overview of different contributions in literature which includes (1) LS (TALS and TFLS), and (2) OL.

\subsection{Leadership Styles (LS)}

Today's competitive organizations demand leadership. Leadership is about behavior first and skills second. Strategic leaders have a vision, are able to influence followers, and are able to transform their vision into action. It all comes back to promoting positive expectations and having those expectations realized. Hallowell (2011) explains, "Using the tool you know best - yourself - to connect with others and help others also connect, you can bring out the best in the people you lead" (p. 98). Leaders believe in change, energize organizations to innovate continuously, recognize the need for synergy, and emphasize the importance of unity and collaboration. Schwartz, Jones, \& McCarthy (2010) explain, "Many organizations build leadership programs around competency models, a list of core skills they expect all leaders to cultivate" (p. 29). Organizations need employees who can be molded into leaders who can influence others to complete tasks and follow the mission of the organization. 
The term leadership means different things to different people. Leadership is both similar and different from management. Management relies more on planning, organizing, and controlling outcomes. There are many connections between leadership and management. As a matter of fact, one major function of a manager is to lead and one major function of a leader is to be able to transform his or her vision into action. Both a manager and a leader must focus on the purpose of the organization, the people within the organization, the plan of the organization, and the priorities of the organization.

Interestingly enough, most people don't seek to be leaders because "as you take the role of a caring leader; people soon begin relating to you differently" (Kouzes\& Posner, 2003, p. 77). A strong leader must have self-confidence and must be able to listen, consult, involve, and explain why and how things should be done. Sheetz-Runkle (2011) states that, "Boldness, decisiveness, commitment, authority, conviction, and right decision making are qualities that influence self-confidence" (p. 45). "Many organizations build leadership programs around competency models, a list of core skills they expect all leaders to cultivate" (Schwartz, Jones, \& McCarthy, 2010, p. 29). Organizations need employees who can be molded into leaders who can influence others to complete tasks and follow the mission of the organization. Leaders are also able to empower followers by "making key behaviors automatic" (Schwartz, Jones, \& McCarthy, 2010, p. 37). Leadership programs have become the norm for many organizations who value strategic leaders. "By embracing our own opposites and getting comfortable with our contradictions, we build richer, deeper lives" and further states, "This is especially crucial for leaders, who must weigh multiple points of view, balance conflicting priorities, serve numerous constituencies, and make decisions about issues with no easy answers" (Schwartz, Jones, \& McCarthy, 2010, p. 29).

Leadership in the workplace is about having vision and being able to transform that vision into action by influencing others to perform at higher levels and promoting the importance of organizational and interpersonal citizenship behaviors. According to Jago (1982), "Leadership is expressed or displayed through interaction between people and necessarily implies its complement, followership. For one to influence, another must permit himself to be influenced" (p. 316).Leaders must embrace the importance of change and treating employees better in order for an organization to thrive in a global and competitive society. "In highly competitive, rapidly changing environments, caring and appreciative leaders are the ones to bet on for long-term success" (Kouzes\& Posner, 2003, p.78).

\subsubsection{Transactional and Transformational Leadership Styles (TALS and TFLS)}

Transactional leadership styles (TALS) involve motivating followers through the exchange of rewards, praises, and promises. Ivey and Kline (2010) state, "Transactional leadership is characterized by leader-follower exchanges, whereby leaders exchange things of value with followers to advance both the leaders' own and followers' agendas" (p. 247). Transformational leadership styles (TFLS) tend to influence workers more positively. Rhodes, Walsh, and Lok (2008) state, "While leaders initiate and drive organizational change, they manage the change only with the help of other change agents. These change agents operate with different change skills and competencies depending on particular requirements and circumstances" (p. 1174). Pounder (2008) explains that the effect of transformational leadership on subordinates centers on three leadership outcomes: (a) the ability of the leader to generate extra effort on the part of those being led, (b) subordinates' perception of leader effectiveness, and (c) their satisfaction with the leader (p. 2). Xirasagar (2008) explains, "Within transactional leadership, three subscales are documented, contingent reward, management-by-exception - active, and management-by-exception - passive" (p. 602). Vecchio, Justin, and Pearce (2008) explain, "Bass and his associates' views on morality relative to transformational and transactional leadership do suggest that transactional leaders would be expected to engage in unethical practices more so than transformational leaders" and further state, "Judgments of a leader's ethical posture may play a particularly strong role in influencing follower satisfaction with the leader" (p.79). Franken, Edwards, and Lambert (2009) explain, "Business leaders are under constant pressure to comply with their demands while maintaining the organization's competitiveness in increasingly complex markets" (p. 49). Effective transformational leaders are able to motivate, empower, and build healthy relationships with their peers throughout an organization. "Over the last decade, considerable research effort has been invested into understanding the processes through which transformational leadership positively relates to follower attitudes, behavior, and performance" (Walumbwa et al., 2008, p. 793). "In prior research, the proposed association of transformational and transactional leadership has been one of augmentation. The augmentation hypothesis argues that transformational leadership will significantly predict leadership criteria after controlling for transactional leadership" (Vecchio, et al, 2008, p.72). When exploring the conditions under which transformational leadership weaves its effects on performance, research results show that "transformational leadership relates to follower identification with work unit and self-efficacy, which interacts with means efficacy to predict individual performance, thus representing a moderated mediation effect" (Walumbwa et al., 2008, p. 815). Another study demonstrated "that instructors displaying transformational leadership qualities in the classroom had a positive and significant influence on student perception of classroom dynamics measured in terms of the three leadership outcomes: extra effort, effectiveness, and satisfaction" 
(Pounder, 2008, p.4). Other researchers argue that "the proposed association of transformational and transactional leadership has been one of augmentation. The augmentation hypothesis argues that transformational leadership will significantly predict leadership criteria after controlling for transactional leadership" (Vecchio et al., 2008, p.72). Jung and Avolio (2000) explain, “Although transactional leadership can be quite effective, it does not involve a leader's commitment toward followers' personal development nor does it involve a strong emotional attachment to the leader" ( $p$. 951). Of course, "employees with higher levels of power distance orientation are less likely to be influenced by transformational leadership behaviors alone and may instead need to be led via different or additional leadership styles" (Kirkman, Chen, Farh, Chen, \& Lowe, 2009, p. 757-758). Kirkman et al., further explain that "individual-level cultural value orientations, and particularly power distance orientation, should not be ignored in studies of the impact of transformational leadership on followers across cultures" (2009, p. 759).

\subsection{Organizational Learning $(O L)$}

As organizations continuously evolve, organizational learning (OL) is expected to be more transparent, collective, and consistent. As a matter of fact, there is a myriad amount of research on organizational learning. According to Franco and Haase (2009), "the concept of organizational learning can be traced back even earlier, to Lev SemenovichVygotsky's studies about child education in the 1920s" (p. 629). Curado (2006) explains, "The scientific conception of knowledge in organizations is still in an early stage of development, although a large and growing body of literature on organizational knowledge, organizational learning, knowledge creation and knowledge management is emerging” (p. 28). Schwartz, Jones, and McCarthy (2010) succinctly address organizational learning, development, and change by pointing out that organizations are dynamic and must be able to compete in this competitive and global society by ad infinitum learning. Holland and Salama (2010) explain, "Organizational learning is dynamic as it involves basic elements of organizational development and growth" and further explain, "Organizations can grow in the traditional sense of increased capital or revenues. From a learning perspective, however, organizations grow when there is an increase in shared understanding involving the organization, its environment and the relationship between the two" (p. 269). Schwartz, Jones, and McCarthy (2010) state, "the defining ethic in the modern workplace is more, bigger, faster. More information than ever is available to us, and the speed of every transaction has increased exponentially, prompting a sense of permanent urgency and endless distraction" (p. 3). Curado (2006) states, "Most researchers consider that organizational learning is the product of organizational members' involvement in the interaction and sharing of experiences and knowledge" (p. 26). Many organizations focus much of their resources on peak performance management also known as productivity levels or efficiency levels relating to job performance. Schwartz, Jones, and McCarthy (2010) explain, "While peak performance is the goal, there are limits to human stamina" (p. 24). Thus, it is imperative to understand that human stamina is limited and that employees are not machines or robots. Organizational learning depends on synergy, effective knowledge management, and creativity. One strategy for reaching peak performance is to work smarter not harder. For example, Sheetz-Runkle (2011) explains how, "Sun Tzu teaches that opportunities must be seized when you're ready and your opponent is not" (p. 30). Instead of working harder than your adversary, it can be smarter to be more prepared. A different strategy would be to use creativity to reach peak performance. Sheetz-Runkle (2011) explains how, “Everybody's creative, including people who don't think they are. Those people just haven't learned how to apply their personal creativity to get results" (p. 36). Caemmerer and Wilson (2010) believe that organizational learning includes "enhanced knowledge and decision making on how to meet performance objectives, improved internal communication and exchange, engagement and cooperation, as well as motivation and commitment to the organization and organizational performance" (p. 290). Thus, the literature review provided a foundation for the research questions and hypotheses.

\section{Research Questions and Hypotheses}

In light of the above-mentioned discussion, this research aims at answering the following questions:

Question1: Are there fundamental differences among the employees at Saudi banks in Al-Taif Governorate towards LS?

Question2: Are there fundamental differences among the employees at Saudi banks in Al-Taif Governorate towards OL?

Question3: What is the relationship between TALS (contingent rewards and management by exception) and OL?

Question4: What is the relationship between TFLS (individualized consideration, charismatic-inspiration and intellectual stimulation) and $O L$ ?

From the above-mentioned research questions, this study attempts to test the following hypotheses:

Hypothesis1: There is no significant discrimination among the employees at Saudi banks in Al-Taif Governorate regarding $L S$. 
Hypothesis2: There is no significant discrimination among the employees at Saudi banks in Al-Taif Governorate regarding $O L$.

Hypothesis3: There is no statistically significant relationship between TALS (contingent rewards and management by exception) and $O L$.

Hypothesis4: There is no statistically significant relationship between TFLS (individualized consideration, charismatic-inspiration and intellectual stimulation) and $O L$.

\section{Research Method}

The research method includes the research population, data collection, research variables, mode of measuring, data analysis and testing hypotheses statistically.

\subsection{Research Population}

The present paper is interested in investigating LS and OL at Saudi banks in Al-Taif Governorate, Kingdom of Saudi Arabia. This is why the population under study involves all categories of employees. Total items of the research population amount to 335. Due to the small number of the research population, the researcher has adopted the census method for data collection. The distribution of the research population is presented in Table 1:

$<$ Table 1 about here $>$

Concerning the job title, managers amounted to about $8.4 \%$, controllers amounted to about $16.5 \%$, chief tellers $26 \%$, tellers $15.1 \%$, and customer services $34 \%$. In regard to marital status, the percentage of the married staff amounted to $71.6 \%$ and single staff $28.4 \%$. As for age, number of participants less than 30 was $41.8 \%$, from 30 to 45 was $50.2 \%$ and more than 45 was about $8.1 \%$. Concerning the educational level, holders of the secondary school certificate amounted to $44.6 \%$, and university education $55.4 \%$. Regarding period of experience, the number of participants less than five years was about $18.2 \%$, from 5 to 10 years was $73 \%$ and more than 10 years of experience was $8.8 \%$. Table 2 illustrates the features of participants.

$<$ Table 2 about here $>$

\subsection{Method of Data Collection}

The present study has adopted the questionnaire method for collecting primary data necessary for the study. The questionnaire list is interested in recognizing LS and OL at Saudi banks. The data of the questionnaire have been collected by contacting employees in informal interviews. The researcher handed them lists of questions and gave them enough time to answer the questions. The completed questions were collected through personal contact again. This is the most broadly employed method for data collecting as it achieves a high rate of responses. The questionnaire list involved three types of questions. The first type is related to recognizing LS, the second type detects OL and the third type is related to the demographic characteristics of employees at Saudi banks. Data collection took two months. Replies were $85 \%, 285$ lists out of the 335 distributed. This is due to the high level of interest of employees in the issue of LS as one of the tools that may be employed for OL at Saudi banks.

\subsection{Research Variables and Method of Measuring}

\subsubsection{Leadership Styles (LS)}

The present study has investigated LS as an independent variable. The researcher has drawn on the scale of Bass \&Avolio (1990) for measuring LS (TALS and TFLS). Twenty-five statements have been modified upon reading a host of studies including (Popper \&Lipshitz, 2000; Jung \&Avolio, 2000; Sarros\&Santora, 2001; Avolio\& Bass, 2002; Stone, et al., 2004; Vera \&Crossan, 2004). There are ten statements for TALS. Statements 1-5 illustrate contingent rewards while statements 6-10 handle management by exception. There are fifteen statements for TFLS. Statements 11-15 illustrate individualized consideration, statements 16-20 handle charismatic-inspiration, and statements 21-25 illustrate intellectual stimulation. It should be indicated that LS has been measured by the five-item scale of Likert of agreement or disagreement where each statement has five options (absolutely agree, agree, neutral, disagree, and absolutely disagree). The informant should select the answer that suits his choice, where (5) indicates full agreement while (1) indicates full disagreement, with neutral degrees in- between.

\subsubsection{Organizational Learning $(\mathrm{OL})$}

The present study has investigated OL as a dependent variable. The researcher has drawn on the scale of Senge et al., 1994 for measuring OL (AOL and GOL). Fourteen statements have been modified upon reading a host of studies including (Voci\& Young, 2001, Smith \& Taylor, 2000, Appeldan\&Goramsson 1997, and Osterberg, 2004). Statements 1-7 illustrate AOL while statements 8-14 handle GOL. It should be indicated that OL has been measured employing 
Likert scale of five points which ranges from fully agreement (5) points to fully disagreement (1) point, while numbers 2 , 3 , and 4 reflect varying degrees of evaluation.

\subsection{Methods of Data Analysis and Testing Hypotheses}

The researcher has drawn on the following statistical methods for data analysis and hypotheses testing (1) the Alpha Correlation Coefficient (ACC), which aims at verifying the degree of reliability in the scale of LS and OL, (2) Multiple Discriminant Analysis (MDA), which aims at discriminating among the employees at Saudi banks regarding LS and OL, (3) Multiple Regression Analysis (MRA), which aims at verifying the type and strength of the relationship between LS and OL, and (4) the statistical testing of hypotheses which includes Chi-square and Wilk's lambda that goes hand in hand with the MDA and F-test and T-test which go with the MRA. All these tests accompany analysis method which has been employed and which are to be used. They are found in Statistical Package for Social Science (SPSS).

\section{Hypotheses Testing}

The findings of analysis may be discussed and explained under the following main headings (1) evaluating reliability of scales, (2) LS, (3) OL, and (4) the relationship between LS and OL.

\subsection{Evaluating Reliability Scales}

The reliability of the scales of LS and OL of the employees at Saudi banks were evaluated to minimize errors of measuring and maximizing constancy of the scales used. ACC was used as it is the most widely employed method of analyzing reliability to evaluate the degree of internal consistency among the contents of the scale under testing. According to scales testing in social research, it was decided to exclude variables that had a correlation coefficient of less than 0.30 when the acceptable limits of ACC range from 0.60 to 0.80 in accordance with levels of reliability analysis in social sciences.

ACC was applied on LS scale in total manner for the entire scale and each variable of the scale separately. The results revealed that ACC for the scale as a whole represented about 0.90 , which is an indication of a high degree of reliability. The extent of internal consistency among contents of LS may be illustrated using ACC throughout the Table 3. This reveals that the primary result of evaluating reliability reflects the fact that the scale under testing is reliable for measuring LS at Saudi banks in Al-Taif Governorate.

$<$ Table 3 about here $>$

Also, ACC was applied on the scale of OL in a total manner for the entire scale and for each variable of the scale. Results of analyzing reliability revealed that ACC of the scale represented about 0.97 , which is an indication of a high degree of reliability. The extent of internal consistency among contents of OL may be revealed using ACC throughout the Table 4. This illustrates that the primary findings of reliability evaluation reflect the fact that the scale under testing is reliable for measuring OL at Saudi banks.

$<$ Table 4 about here $>$

According to the above-mentioned results, two scales were defined; the first is for LS ( 25 variables), where ACC for scales as a whole represented about 0.90 and the second is for OL (14 variables), where ACC for scales as a whole represented 0.97 . These scales are reliable in the course of the later stages of analysis in the study.

\subsection{Leadership Styles (LS)}

This section discusses the results of statistical analysis for answering the first question of this study on the verification of the extent of difference and discrimination among the employees at Saudi banks in Al-Taif Governorate in regard to their evaluative attitudes towards LS and testing the first hypothesis of the study which states:

Hypothesis 1: There is no significant discrimination among the employees at Saudi banks in Al-Taif Governorate regarding $L S$.

The discrimination analysis method was applied on a model including three groups of employees, representing the type of Saudi banks in Al-Taif Governorate, as well as their evaluative attitudes towards LS. The discrimination analysis method was applied on three groups to enable us to answer the previous question as follows:

A. Discriminant Functions and Matrix on the Basis of LS

The functions and matrix at Saudi banks in Al-Taif Governorate are represented in table (5). This table reveals the following findings:

1. Eigenvalues represent 0.24 in the discrimination function among the employees at Saudi banks and their evaluative attitudes towards LS. 
2. There are differences among attitudes of employees at Saudi banks towards LS (the percentage of differentiation which we could interpret in the model was $85 \%$ of discrimination analysis function).

3. There is a significant relationship between employees at Saudi banks and their attitudes towards LS (multiple correlation coefficient represents 0.44 in the discrimination analysis function).

4. Wilks Lambda value represents 0.78 in the discrimination analysis function.

5. Results of discrimination analysis of the three groups revealed that the value of Chi-square represents 71.49 in the discrimination analysis function.

6. The percentage of the accurate classification of employees at Saudi banks in Al-Taif Governorate according to their evaluative attitudes towards LS is $68 \%$, which implies the existence of differences among employees at Saudi banks towards LS. Also, there are about 32\% of the employees at Saudi banks in Al-Taif Governorate who are similar in regard to their evaluative attitudes towards LS (see Table 5).

\section{$<$ Table 5 about here $>$}

\section{B. The Relative Importance of LS}

Using the discrimination analysis method we could define the relative importance of LS and variables which show more discrimination among employees at Saudi banks. It included five variables relating to LS as shown in Table 6.

$<$ Table 6 about here $>$

It is noted that the supervisor is aware of the existence of major differences in individual needs and wishes of the employees. This is the top factor discriminating among employees (discrimination coefficients represent 0.94). The following variables are "my supervisor works on the development of employees by delegating powers" (discrimination coefficient represents 0.88 ), "my supervisor gives me a major opportunity to express my views for the development of the bank" (discrimination coefficient represents 0.83), "my supervisor tells me what needs to be done until I get a reward for the best" (discrimination coefficient represents 0.80 ), and "I negotiate with their supervisor on what they can get for their work" (discrimination coefficient represents 0.78) (See Table 5).

\section{Comparative Description of employees on the Basis of LS}

Comparing the mean of the attitudes of employees towards LS and variables that have more ability to discriminate among them, we could comparatively describe these types, as in Table 6 .

As for employees at the big Saudi banks, they tend to agree, for example, that the supervisor tells them what needs to be done until they get a reward for the best (with a mean of 3.74), the supervisor works on the development of employees by delegating powers (with a mean of 3.71), the supervisor gives them a major opportunity to express their views for the development of the bank (with a mean of 3.64), the employees negotiate with their supervisor on what they can get for their work (with a mean of 3.42), the supervisor is aware of the existence of major differences in individual needs and wishes of the employees (with a mean of 3.24).

As for employees at the middle Saudi banks, they tend to agree, for example, that the supervisor gives them a major opportunity to express their views for the development of the bank (with a mean of 3.78), the employees negotiate with their supervisor on what they can get for their work (with a mean of 3.68), the supervisor works on the development of employees by delegating powers (with a mean of 3.38), the supervisor tells the employees what needs to be done until they get a reward for the best (with a mean of 3.35) and the supervisor is aware of the existence of major differences in individual needs and wishes of the employees (with a mean of 3.21)

As for employees at the small Saudi banks, they tend to agree, for example, that the supervisor gives them a major opportunity to express their views for the development of the bank (with a mean of 4.50), the supervisor is aware of the existence of major differences in individual needs and wishes of the employees (with a mean of 4.13), the employees negotiate with their supervisor on what they can get for their work (with a mean of 3.69), the supervisor tells the employees what needs to be done until they get a reward for the best (with a mean of 3.31) and the supervisor works on the development of employees by delegating powers (with a mean of 3.28).

Accordingly, it was decided to reject the null hypothesis and accept the alternative hypothesis as a whole. This is because it has been clear that there is statistically significant discrimination among the employees at Saudi banks in Al-Taif Governorate on the basis of evaluative attitudes of employees towards LS. This decision was based on the value of Wilks Lambda in the discrimination analysis, which amounts to 0.78 (see table 5). Besides the value of Chi-square calculated (71.49) in the free degree of (10) in the same discrimination analysis function exceeds its table counterpart (23.21) at the level of statistical significance of 0.01 (see table 6). On the other hand, it was decided to reject the same 
null hypothesis of five variables of LS ( 25 variables) taken individually as there is fundamental discrimination among employees on the basis of each variable at a level of statistical significance of 0.01 , according to the test of univariate $\mathrm{F}$ (See Table 6).

\subsection{Organizational Learning $(O L)$}

This section handles results of the statistical analysis for answering the second question of this study on the verification of the extent of difference and discrimination among the employees at Saudi banks in Al-Taif Governorate in regard to their evaluative attitudes towards OL and testing the second hypothesis of the study which states:

Hypothesis2: There is no significant discrimination among the employees at Saudi banks in Al-Taif Governorate regarding $O L$.

The discrimination analysis method was applied on a model including three groups of employees, representing the type of Saudi banks in Al-Taif Governorate, along with their evaluative attitudes towards OL. This technique enabled us to answer the previous question as follows:

A. Discriminant Functions and Matrix on the Basis of OL

The functions and matrix at Saudi banks in Al-Taif Governorate are represented in Table 7. This table reveals the following findings:

1. Eigenvalues represent 0.05 in the discrimination function among the employees at Saudi banks and their evaluative attitudes towards OL.

2. There are differences among attitudes of employees at Saudi banks towards OL (the percentage of differentiation which we could interpret in the model was $69 \%$ of discrimination analysis function).

3. There is a significant relationship between employees at Saudi banks and their attitudes towards OL (multiple correlation coefficient represents 0.22 in the discrimination analysis function).

4. Wilks Lambda value represents 0.93 in the discrimination analysis function.

5. Results of discrimination analysis of the three groups revealed that the value of chi-square represents 19.41 in the discrimination analysis function.

6. The percentage of the accurate classification of employees at Saudi banks in Al-Taif Governorate according to their evaluative attitudes towards OL is $65 \%$, which implies the existence of differences among the employees at Saudi banks towards OL. Also, there are about 35\% of the employees at Saudi banks in Al-Taif Governorate who are similar in regard to their evaluative attitudes towards OL (see Table 7).

$<$ Table 7 about here $>$

Accordingly, it was decided to accept the null hypothesis and reject the alternative hypothesis as a whole. This is because it has been clear that there is no statistically significant discrimination among the employees at Saudi banks in Al-Taif Governorate on the basis of evaluative attitudes of the employees towards OL. This decision was based on the value of Wilks Lambda in the discrimination analysis, which amounts to 0.93 (See table 7). Besides the value of chi-square calculated (19.41) in the free degree of (28) in the same discrimination analysis function was less than its table counterpart (48.28) at the level of statistical significance of 0.01, according to the test of univariate F (See Table 7).

\subsection{The Relationship between $L S$ and $O L$}

This section attempts an answer of the third question in this study on the type and degree of the relationship between LS (TALS and TFLS) and OL along with testing the third hypothesis of the study which states that:

Hypothesis3: There is no statistically significant relationship between LS (TALS and TFLS) and OL at Saudi banks in Al-Taif Governorate, as a whole and for each variable separately.

This hypothesis was divided into two subsidiary hypotheses as follows (1) There is no statistically significant relationship between TALS and OL, and (2) There is no statistically significant relationship between TFLS and OL.

The MRA was used to identify the type and strength of the relationship between LS and OL. Correlation coefficients between them may be illustrated in Table 8 .

$<$ Table 8 about here $>$

This reveals that there is significant correlation between the aspects of LS (TALS and TFLS) and OL at Saudi banks as a whole and for each variable separately.

This section will discuss the relationship between LS (TALS and TFLS) and OL. The MRA was employed to identify 
the type and strength of the relationship between the aspects of LS and OL for the employees separately. Results of applying the MRA are illustrated as follows:

\subsubsection{The Relationship between TALS and OL}

The relationship between TALS and OL are summarized in Table 9 as follows:

$$
<\text { Table } 9 \text { about here }>
$$

Results shown in Table (9) reveal the following:

1. There is a statistically significant relationship between TALS and OL. It represents $48 \%$, according to the multiple correlation coefficients.

2. TALS may interpret about $23 \%$ according to coefficient of determination (R-Square) of the total differentiation in the OL.

3. The variables of the TALS that better interpret differences in the OL, for example, include the facts that "my supervisor requests that I inform him about only things unplanned" (0.468), "I am encouraged by my supervisor to have initiative towards the development of the bank" (0.424), "there is no need to inform my supervisor with all details of my work" (0.401), "the reward system is commensurate with the needs and wishes of the employees" (0.382), "my supervisor does not request except what I should know to accomplish my work" (0.337), "my direct supervisor has instructions to be flexible in granting rewards" (0.272), "I negotiate with my supervisors on what I can get for my work" (0.200), "the effort I exert in my work is commensurate with the returns that I get" (0.156), "my supervisor tells me what needs to be done until I get a reward for the best" (0.135), and "my supervisor does not request except what is necessary to complete the work" (0.002) as Table 9 shows.

In light of the above-mentioned facts, it was decided to reject the null hypothesis which states that there is no significant statistical relationship between TALS as one of the aspects of LS and OL at Saudi banks. The alternative hypothesis has been accepted because the model of MRA has shown that there was fundamental relationship at a statistical significance level of 0.01 (according to F- test) between TALS as an independent variable and OL as a dependent variable at the level of statistical significance level of 0.01 according to T-test (See Table 9).

\subsubsection{The Relationship between TFLS and OL}

Results shown in Table (10) reveal the following:

1. There is a statistically significant relationship between TFLS and OL. It represents $78 \%$, according to the multiple correlation coefficients.

2. TFLS may interpret about $61 \%$ according to coefficient of determination (R-Square) of the total differentiation in the OL.

3. The variables of the TFLS that better interpret differences in the OL, for example, include the facts that "my supervisor encourages everyone around him to carry out the tasks entrusted to them" (0.330), "my supervisor is highly skillful in acquisition and loyalty of bank staff" (0.323), "my supervisor in the bank knows what I want and helps me to get it" (0.202), "my supervisor allows all employees to submit new ideas to solve business problems" (0.161), "my supervisor works mainly on the development of employees by delegating powers" (0.160), "my supervisor has major potential to increase staff motivation and loyalty to the organization" (0.112), "my supervisor encourages employees to provide totally new ideas" (0.112), and "my supervisor is interested in assessment of employees when they do good work" (0.111) as Table 10 shows.

$<$ Table 10 about here $>$

Accordingly, it was decided to reject the null hypothesis which states that there is no significant statistical relationship between TFLS as one of the aspects of LS and OL at Saudi banks in Al-Taif Governorate. The alternative hypothesis has been accepted because the model of MRA has shown that there was fundamental relationship at a statistical significance level of 0.01 (according to F-test) between TFLS as an independent variable and OL as a dependent variable at the level of statistical significance level of 0.01 according to T-test (See Table 10).

\section{Discussion of the Findings}

The present study on analyzing LS and OL at Saudi banks in Al-Taif Governorate, Kingdom of Saudi Arabia reveals a set of results that deserve study and attention. The most important of these results are summarized as follows:

1. There are differences among the employees at Saudi banks in Al-Taif Governorate regarding their evaluative attitudes towards LS. The aspects of LS which better discriminate the employees include the facts that the supervisor is aware of 
the existence of major differences in individual needs and wishes of the employees, the supervisor works on the development of employees by delegating powers, the supervisor gives the employees a major opportunity to express their views for the development of the bank, the supervisor tells the employees what needs to be done until they get a reward for the best, and the employee negotiate with their supervisor on what they can get for their work.

2. There are no differences among the employees at Saudi banks in Al-Taif Governorate regarding their evaluative attitudes towards their OL.

3. There is a statistically significant relationship between the aspects of LS (TALS and TFLS) and OL at Saudi banks in Al-Taif Governorate.

\section{Recommendations}

Empirical results validate the notion that effective TALS and TFLS may lead towards OL. Therefore, the manager needs to take the following factors into account:

1. Organizations should place an emphasis on creating meaningful mission and vision statements that are specific, measurable, attainable, results-driven, and time sensitive. Based upon the mission and vision statements, organizational leaders can create team objectives for each functional area within an organization.

2. TFLS should be facilitated with TALS where applicable. Rewards such as praise and recognition need to be provided in a personalized way for OL.

3. Supervisors need to apply the best LS with the environment employees are working in.

4. It is necessary to pay more attention to OL at Saudi banks. Its officials should realize and spend lavishly on the important OL (AOL and GOL) at Saudi banks as a learning organization. This will achieve success currently and in the future, besides attaining the competitive advantage.

5. Reviewing the methods for selecting administrative leaders of Saudi banks, and the need for attention by choosing individuals with excellent interpersonal skills, out of the importance of leadership in achieving the OL of both types: $\mathrm{AOL}$ and GOL.

6. Taking care of management of Saudi banks, the importance of a TALS in general, and contingent reward, in particular, as it is one of the important elements that can be used to increase OL by rewarding employees in case they work as assigned to them by their managers.

7. The concerned department of Saudi banks should heed the importance of a management by exception as one of the elements leading to the achievement of OL. This can be achieved through expansion in the granting of authority to employees and encouragement of initiative and innovation in the ways and methods of work, including raising the quality and efficiency of performance.

8. Paying attention to Saudi banks and TFLS in order to achieve the best response to the needs and wishes of employees to increase their contribution to the achievement of OL, on the one hand, and raise the performance level of Saudi banks and strengthen their competitiveness, on the other hand.

9. Saudi banks should pay more attention to GOL. This may be accomplished through various means, which include (1) searching for experienced persons in modern management, (2) recognizing the desires and needs of employees, and (3) granting employees more authority for urging them to provide new development in their specialization.

\section{Recommendation for Future Research}

The present study has attempted to disclose the leadership styles and organizational learning at Saudi banks in Al-Taif Governorate, Kingdom of Saudi Arabia, but the scope of the study indicates the existence of other fields for prospective studies of no less importance in this field, including:

The impact of LS on quality improvement.

The role played by TALS and TFLS in the relationship between OL, job performance and job satisfaction.

OL and its impact on some variables like job empowerment, organizational culture, etc. Such studies may be adopted on various communities like universities, directorates of education and public and private hospitals. 


\section{References}

Amitay, M., Popper, M., \&Lipshitz, R. (2005). Leadership style and organizational learning in community clinics. The Learning Organization, 12(1), 57-70. http://dx.doi.org/10.1108/09696470510574269

Appelbaum, S., \&Goransson, L. (1997). Transformational and adaptive learning within the learning organization: A framework for research and application. The Learning Organization, 4(3), 115-128.http://dx.doi.org/10.1108/09696479710182803

Boseman, G. (2008). Effective leadership in a changing world. Journal of Financial Service Professionals, 62(3), 36-38.

Caemmerer, B., \& Wilson, A. (2010). Customer feedback mechanisms and organizational learning in service operations. International Journal of Operations \& Production Management, 30(3), 288-288-311. http://dx.doi.org/10.1108/01443571011024638

Coad, A., \& Berry, A. (1998). Transformational leadership and learning orientation. Leadership \& Organization Development Journal, 19(3), 164-172. http://dx.doi.org/10.1108/01437739810210211

Curado, C. (2006). Organizational learning and design. The Learning Organization, 13(1), 25-48. http://dx.doi.org/10.1108/ 09696470610639112

Edmondson, A. (1999). Psychological safety and learning behavior in work teams,Administrative Science Quarterly, 44, 350-383. http://dx.doi.org/10.2307/2666999

Franco, M., \&Haase, H. (2009). Entrepreneurship: An organizational learning approach. Journal of Small Business and Enterprise Development, 16(4), 628-628-641. http://dx.doi.org/10.1108/14626000911000965

Franken, A., Edwards, C., \& Lambert, R. (2009). Executing strategic change: Understanding the critical management Elements that lead to success. California Management Review, 51 (3), pp. 49-73.

Hallowell, E.M. (2011). Shine: Using brain science to get the best from your people. Harvard, MA: Harvard Business Review.

Holland, W., \&Salama, A. (2010). Organizational learning through international M\&A integration strategies. The Learning Organization, 17(3), 268-268-283. http://dx.doi.org/10.1108/09696471011034946

Ivey, G.W., \& Kline, T.J.B. (2010). Transformational and active transactional leadership in the Canadian military. Leadership \& Organizational Development Journal, 31(3), 246-262. http://dx.doi.org/10.1108/01437731011039352

Jago, A. (1982). Leadership: Perspectives in theory and research. Management Science, 28 (3), pp. 315-336. http://dx.doi.org/10.1287/mnsc.28.3.315

Jung, D., \&Avolio, B. (2000). Opening the black box: An experimental investigation of the mediating effects of trust and value congruence on transformational and transactional leadership. Journal of Organizational Behavior, 21(8), 949-964. http://dx.doi.org/10.1002/1099-1379(200012)21:8<949::AID-JOB64>3.0.CO;2-F

Kirkman, B., Chen, G., Farh, J., Chen, Z., \& Lowe, K. (2009). Individual power distance orientation and follower reactions to transformational leaders: A cross level, cross-cultural examination. Academy of Management Journal, 52(4), pp. 744-764.http://dx.doi.org/10.5465/AMJ.2009.43669971

Kouzes, J., \& Posner, B. (2003). Encouraging the heart. San Francisco, CA: Jossey-Bass.

Lado, A., Boyd, N., \& Wright, P. (1992). A competency-based model of sustainable competitive advantage: Towards a conceptual integration. Journal of Management, 18, 77-91. http://dx.doi.org/10.1177/014920639201800106

Lakomski, G. (2001). Organizational change, leadership and learning: Culture as cognitive process. The International Journal of Educational Management, 15(2), 68-77.http://dx.doi.org/10.1108/09513540110383791

Lien, B., Hung, R., \& McLean, G. (2007). Organizational learning as an organization development intervention in six high- technology firms in Taiwan: An exploratory case study. Human Resource Development Quarterly, 18(2), 211-228.http://dx.doi.org/10.1002/hrdq.1200

Lipshitz, R., Popper, M., \& Friedman, V. (2002). A multi-facet model of organizational learning. Journal of Applied Behavioral Science, 38, 78-98.http://dx.doi.org/10.1177/0021886302381005

Österberg, P. (2004). Generative learning management: A hypothetical model. The Learning Organization, 11(2), 145-158. http://dx.doi.org/10.1108/09696470410521600

Popper, M., \&Lipshitz, R. (2000). Installing mechanisms and instilling values: The role of leaders in organizational learning. The Learning Organization, 7(3), 135-144. http://dx.doi.org/10.1108/09696470010335854 
Pounder, J. (2008). Transformational leadership: Practicing what we teach in the Management classroom. Journal of Education for Business, 84 (1), pp. 2-6. Rhodes, J.http://dx.doi.org/10.1080/09585190802051477

Walsh, P., \&Lok, P. (2008). Convergence and divergence issues in strategic management: Indonesia's experience with the balanced scorecard in HR management. International Journal ofHuman Resources Management, 19(6), $1170-1185$.

Riaz, A., \&Haider, M. (2010). Role of transformational and transactional leadership on job satisfaction and career satisfaction. Business and Economic Horizons, 1(1), 29-38.

Rowe, W. (2001). Creating wealth in organizations: The role of strategic leadership. Academy of Management Executive, 15, 81-94. http://dx.doi.org/10.5465/AME.2001.4251395

Sarros, J., \&Santora, J. (2001). The transformational-transactional leadership model in practice. Leadership \& Organization Development Journal, 22 (8), 383-393.http://dx.doi.org/10.1108/01437730110410107

Schwartz, T., Jones, J., \& McCarthy, C. (2010). The way we're working isn't working. New York, NY: Free Press.

Sheetz-Runkle, B. (2011). Sun Tzu for women: The art of war for winning in business. Cincinnati, OH: Adams Business.

Stone, A., Russell, R., \& Patterson, K. (2004). Transformational versus servant leadership: A difference in leader focus. Leadership \& Organizational Development Journal, 25(4), 349-361. http://dx.doi.org/10.1108/01437730410538671

Vecchio, R., Justin, J., \& Pearce, C. (2008). The utility of transactional and transformational leadership for predicting performance and satisfaction within a path-goal theory framework. Journal of Occupational and Organizational Psychology, 81 (1), pp. 71-82.http://dx.doi.org/10.1348/096317907X202482

Walumbwa, F., Avolio, B., \& Zhu, W. (2008). How transformationalleadership weaves its influence on individual job performance: the role of identification and efficacy beliefs. Personnel Psychology, 61(4), pp. 793-825. http://dx.doi.org/10.1111/j.1744-6570.2008.00131.x

Xirasagar, S. (2008). Transformational, transactional and laissez-faire leadership among physician executives. Journal of Health Organization and Management, 22(6), 599-613. http://dx.doi.org/10.1108/14777260810916579

Zhu, W., Chew, I., \& Spangler, W. (2005). CEO transformational leadership and organizational outcomes: The mediating role of human-capital-enhancing human resource management. The Leadership Quarterly, 16, 39-52. http://dx.doi.org/10.1016/j.leaqua.2004.06.001

Table 1. Distribution of the Research Population

\begin{tabular}{|c|c|c|}
\hline The Name of the Bank & Number & Percentage \\
\hline Al-Rajhey & 124 & $37 \%$ \\
\hline Al-Ahley & 96 & $29 \%$ \\
\hline Al-Riyadh & 37 & $11 \%$ \\
\hline Al-Arabey & 22 & $7 \%$ \\
\hline Al-Belad & 19 & $6 \%$ \\
\hline Samba & 15 & $4 \%$ \\
\hline SAB & 11 & $3 \%$ \\
\hline Al-Frencey & 11 & $3 \%$ \\
\hline Total & $\mathbf{3 3 5}$ & $\mathbf{1 0 0} \%$ \\
\hline
\end{tabular}

Source: Al-Taif Governorate, KSA, 2010 
Table 2. Characteristics of Participants

\begin{tabular}{|c|c|c|c|}
\hline \multicolumn{2}{|c|}{ Variables } & Number & Percentage \\
\hline \multirow{5}{*}{ 1- Job Title } & Managers & 24 & $8.4 \%$ \\
\hline & Controllers & 47 & $16.5 \%$ \\
\hline & Chief Tellers & 74 & $26.0 \%$ \\
\hline & Tellers & 43 & $15.1 \%$ \\
\hline & Customer Services & 97 & $34.0 \%$ \\
\hline & Total & 285 & $100 \%$ \\
\hline \multirow{3}{*}{ 2- Marital Status } & Married & 204 & $71.6 \%$ \\
\hline & Single & 81 & $28.4 \%$ \\
\hline & Total & 285 & $100 \%$ \\
\hline \multirow{4}{*}{ 3- Age } & Less than 30 years & 119 & $41.8 \%$ \\
\hline & From 30 to 45 & 143 & $50.2 \%$ \\
\hline & More than 45 & 23 & $8.1 \%$ \\
\hline & Total & 285 & $100 \%$ \\
\hline \multirow{3}{*}{ 4- Educational Level } & Secondary School & 127 & $44.6 \%$ \\
\hline & University Education & 158 & $55.4 \%$ \\
\hline & Total & 285 & $100 \%$ \\
\hline \multirow{4}{*}{$\begin{array}{l}\text { 5- Period of } \\
\text { Experience }\end{array}$} & Less than 5 years & 52 & $18.2 \%$ \\
\hline & From 5 to 10 & 208 & $73.0 \%$ \\
\hline & More than 10 & 25 & $8.8 \%$ \\
\hline & Total & 285 & $100 \%$ \\
\hline
\end{tabular}

Source: Saudi Arabia Monetary Agency, Al-Taif Governorate, KSA, 2011

Table 3. Evaluation of the Internal Consistency among Contents of LS

Using ACC, The Output of Reliability Analysis

\begin{tabular}{|c|c|c|}
\hline $\begin{array}{c}\text { The Dimension of } \\
\text { LS }\end{array}$ & $\begin{array}{c}\text { Number of } \\
\text { Statement }\end{array}$ & $\begin{array}{c}\text { Alpha Correlation } \\
\text { Coefficient }\end{array}$ \\
\hline $\begin{array}{c}\text { Transactional Leadership Styles } \\
\text { (TALS) }\end{array}$ & 10 & 0.81 \\
\hline $\begin{array}{c}\text { Transformational Leadership Styles } \\
\text { (TFLS) }\end{array}$ & 15 & 0.89 \\
\hline Total Measurement for LS & 25 & 0.90 \\
\hline
\end{tabular}

Table 4. Evaluation of the Internal Consistency among Contents of OL

Using ACC, The Output of Reliability Analysis

\begin{tabular}{|c|c|c|}
\hline The Dimension ofOL & $\begin{array}{c}\text { Number of } \\
\text { Statement }\end{array}$ & $\begin{array}{c}\text { Alpha Correlation } \\
\text { Coefficient }\end{array}$ \\
\hline Adaptive Organizational Learning (AOL) & 7 & 0.95 \\
\hline $\begin{array}{c}\text { Generative Organizational Learning } \\
\text { (GOL) }\end{array}$ & 7 & 0.93 \\
\hline Total Measurement & $\mathbf{1 4}$ & $\mathbf{0 . 9 7}$ \\
\hline
\end{tabular}


Table 5. Discriminant Functions and Matrix on the Basis of LS

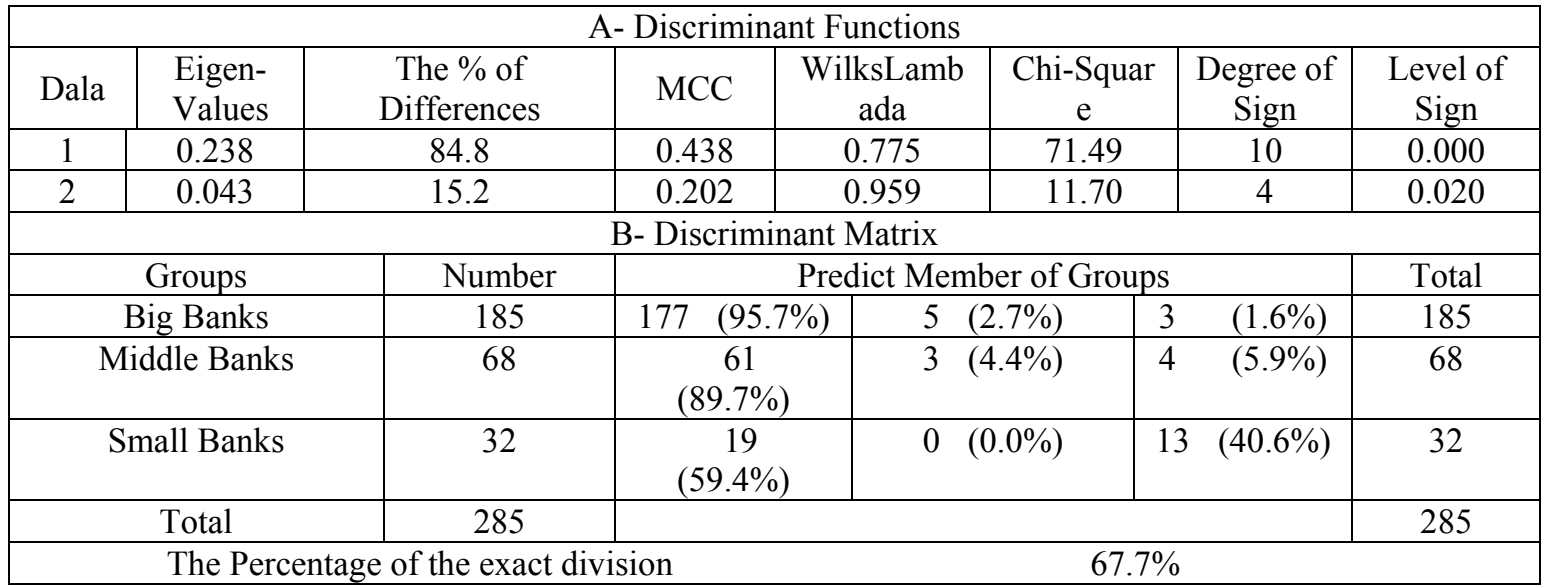

Table 6. Discrimination Coefficients among the Employees on the Basis of LS

\begin{tabular}{|c|c|c|c|c|c|}
\hline \multirow[b]{2}{*}{$\begin{array}{c}\text { The Factor Discriminating among } \\
\text { Employees at the Saudi Banks }\end{array}$} & \multicolumn{3}{|c|}{ Mean } & \multirow[b]{2}{*}{ F-Test } & \multirow[b]{2}{*}{$\begin{array}{l}\text { Level } \\
\text { of Sig }\end{array}$} \\
\hline & $\begin{array}{c}\text { Group } \\
1 \\
\end{array}$ & $\begin{array}{c}\text { Group } \\
2 \\
\end{array}$ & $\begin{array}{c}\text { Group } \\
\mathbf{3} \\
\end{array}$ & & \\
\hline $\begin{array}{l}\text { 1. My supervisor is aware of the existence } \\
\text { of major differences in individual needs } \\
\text { and wishes of the employees. }\end{array}$ & 3.24 & 3.21 & 4.13 & $8.959^{* *}$ & 0.940 \\
\hline $\begin{array}{l}\text { 2. My supervisor works on the development } \\
\text { of employees by delegating powers. }\end{array}$ & 3.71 & 3.38 & 3.28 & $9.153^{* *}$ & 0.881 \\
\hline $\begin{array}{l}\text { 3. My supervisor gives me a major } \\
\text { opportunity to express my views for the } \\
\text { development of the bank. }\end{array}$ & 3.64 & 3.78 & 4.50 & $9.351^{* *}$ & 0.826 \\
\hline $\begin{array}{l}\text { 4. My supervisor tells me what needs to be } \\
\text { done until I get a reward for the best. }\end{array}$ & 3.74 & 3.35 & 3.31 & $8.044^{* *}$ & 0.804 \\
\hline $\begin{array}{l}\text { 5. I negotiate with my supervisor on what I } \\
\text { can get for my work. }\end{array}$ & 3.42 & 3.68 & 3.69 & $7.571^{* *}$ & 0.775 \\
\hline
\end{tabular}

Table 7. Discriminant Functions and Matrix on the Basis of OL

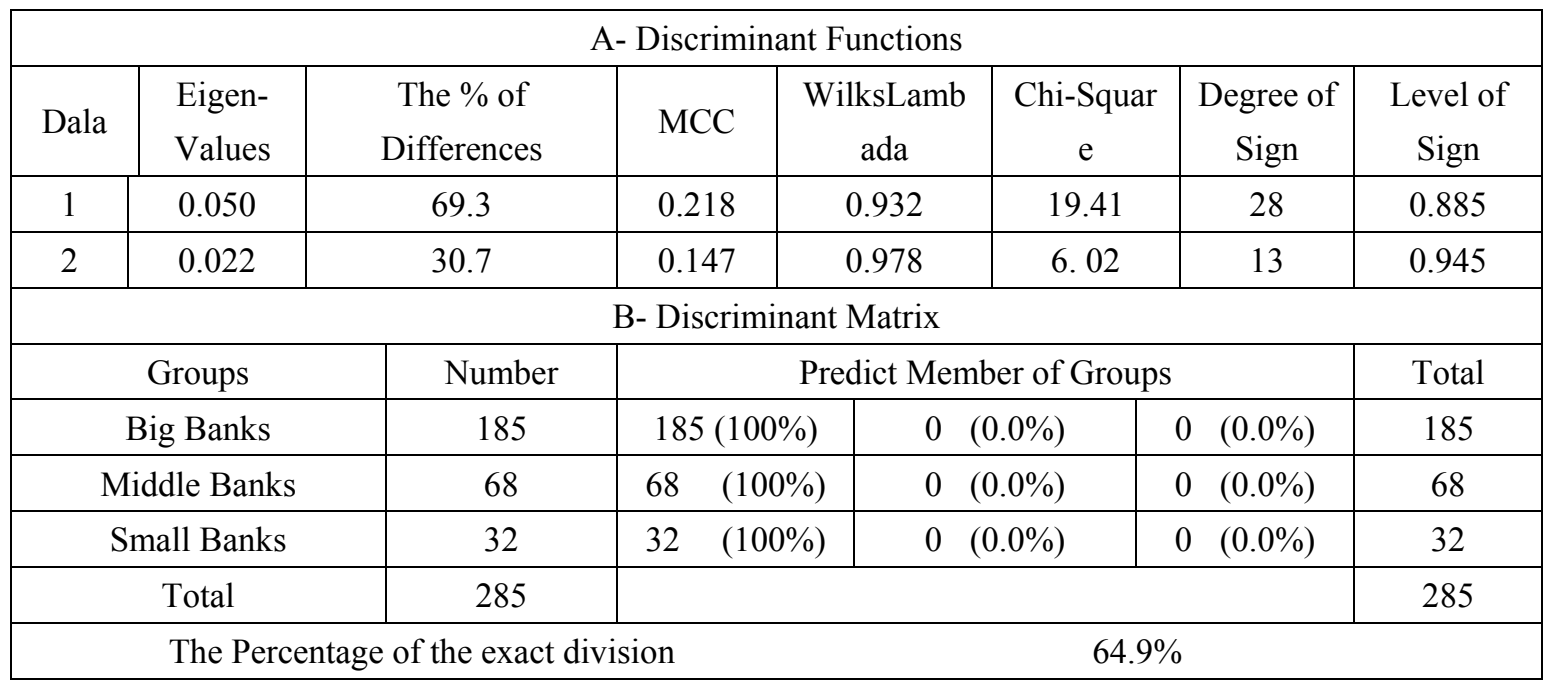


Table 8. Correlation Coefficients between LS (TALS and TFLS) OL

\begin{tabular}{|c|c|c|c|c|}
\hline & \multirow[t]{2}{*}{ The Dimension of LS } & \multicolumn{2}{|c|}{$\begin{array}{c}\text { The Dimension } \\
\text { of OL }\end{array}$} & \multirow{2}{*}{$\begin{array}{c}\text { Total } \\
\text { OL }\end{array}$} \\
\hline & & AOL & GOL & \\
\hline \multirow{2}{*}{ TALS } & Contingent Rewards & 0.343 & 0.352 & \multirow{2}{*}{0.36} \\
\hline & Management by Exception & 0.359 & 0.352 & \\
\hline \multicolumn{2}{|r|}{ Total Measurement } & 0.354 & 0.355 & \\
\hline \multirow{3}{*}{ TFLS } & Individual Considerations & 0.564 & 0.563 & \multirow{3}{*}{0.66} \\
\hline & Charismatic-Inspiration & 0.711 & 0.708 & \\
\hline & Intellectual Simulation & 0.550 & 0.546 & \\
\hline \multicolumn{2}{|r|}{ Total Measurement } & 0.665 & 0.663 & \\
\hline
\end{tabular}

Table 9. The Relationship between TALS and OL

\begin{tabular}{|c|c|c|c|}
\hline The Variables of TALS & Beta & $\mathrm{R}$ & $\mathrm{R}^{2}$ \\
\hline $\begin{array}{l}\text { My supervisor tells me what needs to be done until I get a } \\
\text { reward for the best. }\end{array}$ & 0.135 & 0.294 & 0.086 \\
\hline $\begin{array}{l}\text { The effort I exert in my work is commensurate with the } \\
\text { returns that I get it. }\end{array}$ & 0.156 & 0.369 & 0.136 \\
\hline $\begin{array}{l}\text { I negotiate with my supervisors on what I can get for my } \\
\text { work. }\end{array}$ & 0.200 & 0.363 & 0.132 \\
\hline $\begin{array}{l}\text { My direct supervisor has instructions to be flexible in granting } \\
\text { rewards. }\end{array}$ & 0.272 & 0.027 & 0.007 \\
\hline $\begin{array}{l}\text { The reward system is commensurate with the needs and } \\
\text { wishes of the employees. }\end{array}$ & 0.382 & 0.116 & 0.013 \\
\hline $\begin{array}{l}\text { My supervisor does not request except what is necessary to } \\
\text { complete the work. }\end{array}$ & 0.002 & 0.300 & 0.090 \\
\hline $\begin{array}{l}\text { I am encouraged by my supervisor to have initiative towards } \\
\text { the development of the bank. }\end{array}$ & $0.424^{*}$ & 0.390 & 0.152 \\
\hline $\begin{array}{l}\text { My supervisor does not request except what I should know to } \\
\text { accomplish my work. }\end{array}$ & 0.337 & 0.368 & 0.135 \\
\hline $\begin{array}{l}\text { There is no need to inform my supervisor with all details of } \\
\text { my work. }\end{array}$ & 0.401 & 0.048 & 0.002 \\
\hline $\begin{array}{l}\text { My supervisor requests that I inform him about only things } \\
\text { unplanned. }\end{array}$ & 0.468 & 0.135 & 0.018 \\
\hline $\begin{array}{ll} & \text { Multiple Correlation Coefficients } \\
\text { - } & \text { Coefficient of Determination } \\
\text { - } & \text { Degree of Freedom } \\
\text { - } & \text { The Value of Indexed F } \\
\end{array}$ & & $\begin{array}{c}0.480 \\
0.230 \\
8.193 \\
10,274 \\
2.320 \\
0.000\end{array}$ & \\
\hline$* \mathrm{P}<.05$ & & & \\
\hline
\end{tabular}


Table 10. The Relationship between TFLS and OL

\begin{tabular}{|c|c|c|c|}
\hline The Variables of TFLS & Beta & $\mathrm{R}$ & $\mathrm{R}^{2}$ \\
\hline $\begin{array}{l}\text { My supervisor is interested in employees believed to } \\
\text { neglect their work. }\end{array}$ & 0.020 & 0.347 & 0.120 \\
\hline $\begin{array}{l}\text { My supervisor in the bank knows what I want and helps } \\
\text { me to get it. }\end{array}$ & $0.202^{* *}$ & 0.321 & 0.103 \\
\hline $\begin{array}{l}\text { My supervisor is interested in assessment of employees } \\
\text { when they do good work. }\end{array}$ & 0.111 & 0.315 & 0.099 \\
\hline $\begin{array}{l}\text { My supervisor is aware of the existence of differences in } \\
\text { individual needs and wishes of the employees. }\end{array}$ & 0.030 & 0.470 & 0.221 \\
\hline $\begin{array}{l}\text { My supervisor works mainly on the development of } \\
\text { employees by delegating powers. }\end{array}$ & $0.160^{* *}$ & 0.428 & 0.183 \\
\hline $\begin{array}{l}\text { My supervisor encourages everyone around him to carry } \\
\text { out the tasks entrusted to them. }\end{array}$ & $0.330^{* *}$ & 0.615 & 0.378 \\
\hline $\begin{array}{l}\text { My supervisor is highly skillful in acquisition and loyalty } \\
\text { of bank staff. }\end{array}$ & $0.323^{* *}$ & 0.607 & 0.368 \\
\hline $\begin{array}{l}\text { My supervisor has major potential to increase staff } \\
\text { motivation and loyalty to the organization. }\end{array}$ & 0.112 & 0.605 & 0.366 \\
\hline $\begin{array}{l}\text { My supervisor gives me a major opportunity to express } \\
\text { my views for the development of the bank. }\end{array}$ & 0.032 & 0.497 & 0.247 \\
\hline $\begin{array}{l}\text { My supervisor plays a role which is a model of respect for } \\
\text { all employees. }\end{array}$ & 0.059 & 0.300 & 0.090 \\
\hline $\begin{array}{l}\text { My supervisor gives directives that force me to rethink } \\
\text { some of my own work. }\end{array}$ & 0.036 & 0.390 & 0.152 \\
\hline $\begin{array}{l}\text { My supervisor gives me a major opportunity to think } \\
\text { about old problems in new ways. }\end{array}$ & 0.056 & 0.368 & 0.135 \\
\hline $\begin{array}{l}\text { My supervisor provides me with new ways to develop my } \\
\text { perspective on things. }\end{array}$ & 0.022 & 0.347 & 0.120 \\
\hline $\begin{array}{l}\text { My supervisor encourages employees to provide totally } \\
\text { new ideas. }\end{array}$ & $0.112^{*}$ & 0.315 & 0.099 \\
\hline $\begin{array}{l}\text { My supervisor allows all employees to submit new ideas } \\
\text { to solve business problems. }\end{array}$ & $0.161^{* *}$ & 0.428 & 0.183 \\
\hline 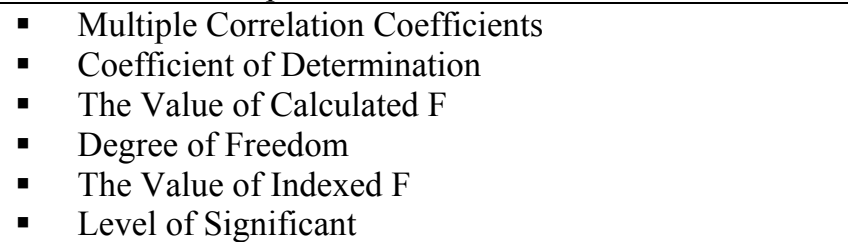 & \multicolumn{3}{|c|}{$\begin{array}{c}0.780 \\
0.608 \\
35.164 \\
12,272 \\
2.184 \\
0.000\end{array}$} \\
\hline$* * \mathrm{P}<.01$ & & & \\
\hline
\end{tabular}

